\title{
AKTIVITAS ANTIMIKROBA EKSTRAK ETIL ASETAT JAMUR LAUT YANG DIISOLASI DARI KARANG LUNAK Sarcophyton sp. DARI PERAIRAN DESA TUMBAK KECAMATAN PUSOMAEN
}

\author{
Englin Meiva Paat ${ }^{1)}$, Defny S. Wewengkang ${ }^{1)}$, Henki Rotinsulu ${ }^{1)}$ \\ ${ }^{1)}$ Program Studi Farmasi FMIPA UNSRAT Manado, 95115
}

\begin{abstract}
Soft coral is one type of Coelenterata that lives at sea, namely coral reef waters. Soft Coral acts as one of the constituent animals of coral reef ecosystems and is the largest supplier of growth compounds, such as carbonate compounds in which 50\% of the bioactive compounds found in these invertebrates are toxic. This study aims to determine the antimicrobial activity of marine fungi associated with soft coral Sarcophyton sp., which was obtained from Tumbak Village, Posumaen Sub-district, Southeast Minahasa Regency, North Sulawesi. The antimicrobial testing uses diffusion methods to determine the inhibitory activity against Staphylococcus aureus (Gram positive bacteria), Escherichia coli (Gram negative bacteria) and Candida albicans (fungi). The results showed that the antimicrobial activity of fungal extracts isolated from soft coral Sarcophyton sp., against bacteria, Escherechia coli, and Candida albicans by measuring the inhibitory activity is the formation of clear zones which categorize as medium, whereas for Staphylococcus aureus bacteria do not have antimicrobial activity.
\end{abstract}

Keywords: Antimicrobial, Soft Coral (Sarcophyton sp.), Staphylococcus aureus, Eschrichia coli, Candida albicans

\begin{abstract}
ABSTRAK
Karang Lunak merupakan salah satu jenis Coelenterata yang hidupnya dilaut yaitu perairan terumbu karang. Karang Lunak berperan sebagai salah satu hewan penyusun ekosistem terumbu karang dan pemasok senyawa pertumbuhan terbesar yaitu senyawa karbonat yang dimana sebanyak $50 \%$ senyawa bioaktif yang terdapat pada invetebrata ini bersifat toksik. Penelitian ini bertujuan untuk mengetahui adanya aktivitas antimikroba dari jamur laut yang berasosisasi dengan karang lunak Sarcophyton sp., yang diperoleh dari desa Tumbak Kecamatan Posumaen Minahasa Tenggara Sulawesi Utara. Pengujian daya antimikroba menggunakan metode difusi untuk mengetahui aktivitas penghambatan yang diuji terhadap Staphylococcus aureus (bakteri Gram positif), Eschrichia coli (bakteri Gram negatif) dan Candida albicans (jamur). Hasil penelitian menunjukkan bahwa adanya aktivitas antimikroba ekstrak jamur yang diisolasi dari karang lunak Sarcophyton sp., terhadap bakteri, Escherechia coli, dan jamur Candida albicans dengan pengukuran daya hambat yaitu terbentuknya zona bening yang ada dalam kategori sedang, sedangkan untuk bakteri Staphylococcus aureus tidak memiliki aktivitas antimikroba.
\end{abstract}

Kata Kunci: Antimikroba, Karang Lunak (Sarcophyton sp.), Staphylococcus aureus, Eschrichia coli, Candida albicans 


\section{PENDAHULUAN}

Indonesia merupakan Negera kepulauan terbesar di dunia yang mempunyai panjang pantai $81.000 \mathrm{~km}$ yang kaya akan terumbu karang dan biota laut lainnya (Van Soest, 1989). Hampir seluruh perairan yang berada di Indonesia terdapat karang lunak dengan tingkat keanekaragamannya yang tinggi (Mahaza, 2003). Karang lunak (soft coral) merupakan bagian dari ekosistem terumbu karang yang penting (Benayahu, 1985) dan termasuk komponen terbesar setelah karang batu (Manuputty, 1996).

Karang lunak berperan sebagai salah satu hewan penyusun ekosistem terumbu karang serta pemasok senyawa pertumbuhan terbesar bagi terumbu karang yaitu senyawa karbonat, hal ini dibuktikan dengan penemuan sejumlah besar spikula berkapur di dalam jaringan tubuhnya dan ini tidak ditemukan pada hewan-hewan lain yang hidup sekalipun diterumbu karang yang sama.

Sarcophyton sp., merupakan salah satu jenis karang lunak yang memproduksi senyawa kimia alami dan dikenal dengan istilah produk alami. Senyawa kimia alami tersebut berpotensi sebagai sumber obat alami. Senyawa kimia aktif yang terdapat pada karang lunak Sarcophyton sp., menunjukkan aktivitas sebagai antibakteri, antifungi, antitumor, neurotoksik, dan antiinflamantori yang bermanfaat bagi industry farmasi (Badria et al, 1998) dan (Sawant et al, 2006).

Sekarang ini perkembangan resistensi terhadap antimikroba dan munculnya patogen multiresisten telah membangkitkan kepedulian kalangan medis di dunia. Hal ini telah menjadi permasalahan yang sangat penting untuk diselesaikan. Karena itu diperlukan penemuan dan pengembangan jenis antibiotik baru yang dapat melawan mekanisme resistensi. Resistensi mikroorganisme terhadap obat-obat yang beredar menyebabkan banyak peneliti berusaha mencari bahan-bahan antibiotik baru. Informasi mengenai kandungan antibiotik dari jamur simbion karang lunak masih kurang sehingga penelitian tentang mikroorganisme yang bersimbiosis dengan karang lunak dari perairan Sulawesi Utara, khususnya di perairan Desa Tumbak, Kecamatan Posumea, Kabupaten Minahasa Tenggara sangat di perlukan.

\section{METODOLOGI PENELITIAN}

\section{Tempat dan Waktu Penelitian}

Penelitian ini dilaksanakan pada bulan Oktober 2019 - November 2019 di Laboratorium Farmasi Lanjut Fakultas Matematika dan Imu Pengetahuan Alam Universitas Sam Ratulangi.

\section{Bentuk Penelitian}

Penelitian ini merupakan eksperimental laboratorium yang akan menguji aktivitas antimikroba jamur dan bakteri yang diisolasi dari karang lunak Sarcophyton Sp.

\section{Alat dan Bahan}

Alat

Alat yang digunakan dalam penelitian ini yaitu masker, sarung tangan, gunting, tabung oksigen, snorkel, fins, kantong plastik, kamera bawah laut, wadah kaca, pisau, Erlenmeyer, corong, rotary evaporator, timbangan analitik, corong pisah, gelas ukur, gelas kimia, cawan petri, autoklaf, pinset, pembakar spritus, magnetic stirrer, pipet tetes, mikro 
tub, batang pengaduk, Laminar air flow, rak tabung reaksi, tabung reaksi, lemari pendingin, vial, jangka sorong, jarum ose inkubator, cakram (paper disc), mikropipet, jas lab.

\section{Bahan}

Bahan-bahan yang digunakan yaitu Karang lunak Sarcophyton sp., bakteri uji Staphylococcus aureus ATCC 25923, Escherichia coli ATCC 25922, Jamur Uji Candida albicans ATCC 1231, etanol, aquadest, etil asetat, aseton, Potato Dextros Agar, Nutrient Agar, Glukosa, Polypeptone, $\mathrm{MgSO}_{4} .7 \mathrm{H}_{2} \mathrm{O}$, Yeast Extract, $\mathrm{KH}_{2} \mathrm{PO}_{4}$, Sukrosa, Starch, Malt Extract, Ebios, kloramfenikol paperdisc, label, spidol permanen, tissue, aluminium foil, kertas saring, kapas.

\section{Prosedur Kerja}

\section{Pengambilan Sampel}

Sampel karang lunak diambil di Desa Tumbak, Kecamatan Pusomaen, Kabupaten Minahasa Tenggara. menggunakan alat bantu (Scuba Diving). Sampel difoto dengan kamera bawah laut dan diambil lalu dimasukkan ke dalam ziper bag dan disimpan dalam cooling box berisi es batu untuk dibawa ke Laboratorium Lanjutan Program Studi Farmasi Fakultas Matematika dan Imu Pengetahuan Alam Universitas Sam Ratulangi.

\section{Determinasi Karang Lunak}

Determinasi karang lunak dilakukan dilakukan di Laboratorium Lanjut Program Studi Farmasi Universitas Sam Ratulangi Manado. Tujuan dilakukan determinasi yaitu untuk mengetahui sampel yang diambil, dari hasil determinasi ini menunjukan karang lunak
Sarcophyton sp., yang digunakan dalam penelitian ini.

\section{Kultur Cair}

Kultur cair dibuat dengan cara biarkan jamur murni yang telah diperoleh diinokulasikan ke dalam labu Erlenmeyer yang berisi (2 gram glukosa, 0,5 gram polypeptone, 0,05 gram $\mathrm{MgSO}_{4} \cdot 7 \mathrm{H}_{2} \mathrm{O}, 0,2$ gram yeast extract, 0,1 gram $\mathrm{KH}_{2} \mathrm{PO}_{4}, 0,1$ gram agar dilarutkan dalam $100 \mathrm{ml}$ aquades). Labu tersebut kemudian diaduk menggunakan alat shaker pada suhu $27^{\circ} \mathrm{C}$ dengan kecepatan $120 \mathrm{rpm}$ selama 3x24 jam untuk memperoleh bibit kultur. Setelah didapat bibit kultur, kemudian dipindahkan sebanyak $3 \mathrm{ml}$ ke media produksi yang berisi (4,5 gram sukrosa, 4,5 gram starch, 1,5 gram extract Malt, 0,45 gram ebios, 0,75 $\mathrm{KH}_{2} \mathrm{PO}_{4}, 0,075$ gram $\mathrm{MgSO}_{4} 7 \mathrm{H}_{2} \mathrm{O}$ dilarutkan dalam $150 \mathrm{ml}$ aquades). Labu tersebut kemudian diaduk menggunakan alat shaker pada suhu $27^{\circ} \mathrm{C}$ dengan kecepatan 120 rpm selama 14x24 jam (Yamazaki et al., 2012).

\section{Isolasi dan Purifikasi Jamur yang Berasosiasi dengan Karang Lunak}

Isolasi jamur dilakukan dengan cara sampel dibersihkan dengan aquades kemudian dipotong kecil-kecil seperti dadu menggunakan gunting dan pinset dan dimasukkan ke dalam media PDA yang telah disediakan. Sampel ditanam di atas media PDA dengan tiga titik pusat yang berbentuk segitiga. Cawan petri yang berisi sampel ditutup dan direkatkan menggunakan parafilm, kemudian diinkubasi pada suhu ruangan selama $7 \times 24$ jam. Setelah didapatkan isolat jamur, dilakukan pemurnian dengan cara isolat. jamur diinokulasikan ke media PDA yang 
baru, kemudian di inkubasi pada suhu ruangan selama $14 \times 24$ jam. Selanjutnya diidentifikasi morfologi secara makroskopik untuk menghasilkan isolat jamur murni.

\section{Ekstraksi dan Fraksinasi}

Pada akhir hari ke empat belas setelah proses fermentasi, dilakukan ekstraksi pada campuran miselium jamur dan broth dengan menggunakan $200 \mathrm{ml}$ aseton. Ekstraksi dilakukan dengan menggunakan shaker pada suhu ruangan dengan kecepatan 150 rpm selama 5 menit. Selanjutnya dipisahkan antara fase air dan aseton menggunakan corong pisah dan kertas saring. Setelah didaptkan filtrat dari hasil penyaringan kemudian diuapkan dengan rotary evaporator untuk menguapkan pelarut dan memperoleh senyawa hasil ekstraksi yang diinginkan. Dari proses ini didapatkan ekstrak cair, kemudian ekstrak cair dimasukkan ke dalam corong pisah untuk dilakukan fraksinasi. Fraksinasi yang dilakukan menggunakan pelarut etil asetat sebanyak $200 \mathrm{ml}$ setelah itu dikocok dalam corong pisah sampai homogen. Dibiarkan sampai terbentuk dua lapisan. Masing-masing lapisan ditampung pada wadah yang berbeda. Lapisan $\mathrm{H}_{2} \mathrm{O}$ kemudian difraksinasi lagi menggunakan pelarut etil asetat sebanyak $200 \mathrm{ml}$. Hal ini dilakukan sebanyak tiga kali. Selanjutnya fraksi etil asetat dikumpulkan kemudian pelarut diuapkan menggunakan rotary evaporator sampai diperoleh ekstrak kasar yang akan digunakan untuk uji aktivitas antimikroba.

\section{Pengujian aktivitas antimikroba}

Metode yang digunakan dalam penelitian ini yaitu metode difusi agar (disc diffusion Kirby and Bauer). Aktivitas penghambatannya diuji terhadap Staphylococcus aureus ATCC 25923 (bakteri Gram positif), Eschrichia coli ATCC 25922 (bakteri Gram negatif) dan Candida albicans ATCC 1231 (jamur), yang digunakan sebagai mikroorganisme uji. Pada pengujian aktivitas antimikroba ini, cakram (paper disc) yang digunakan berukuran $6 \mathrm{~mm}$. Suspensi mikroba kemudian diinokulasikan ke dalam media dan dihomogenkan. Kemudian media yang telah diinokulasi mikroba dituangkan ke dalam cawan petri dan tunggu sampai media memadat. Masing-masing cawan petri diberi label dan nomor sampel yang sesuai. Sampel yang telah ditentukkan konsentrasinya $(250 \mu \mathrm{g} / 50 \mu \mathrm{l})$ ditotolkan pada masing-masing cakram dengan menggunakan mikropipet. Letakkan kertas cakram yang telah ditotolkan sampel uji dengan pinset kedalam cawan petri lalu diinkubasi selama 1 x 24 jam (Ortez, 2005).

\section{Pengamatan dan Pengukuran Zona Hambat}

Pengamatan dilakukan setelah $1 \times 24$ jam masa inkubasi. Zona bening merupakan petunjuk kepekaan mikroba terhadap bahan antimikroba yang digunakan sebagai bahan uji yang dinyatakan dengan lebar diameter zona hambat (Vandepitte et al, 2011). Diameter zona hambat diukur kemudian dikategorikan kekuatan daya antimikrobanya berdasarkan penggolongan Davis dan Stout (1971).

\section{Pengolahan dan Analisis Data}

Teknik pengolahan data dilakukan dengan model penyajian dalam bentuk 
tabel dan gambar. Aktivitas antibakteri diukur dengan menggunakan jangka sorong dijital skala millimeter berdasarkan zona hambat yang terbentuk, kemudian dirata-ratakan dari tiga kali pengujian.

\section{HASIL DAN PEMBAHASAN Uji Aktivitas Antimikroba}

Uji aktivitas antimikroba dari jamur yang berasosiasi dengan karang lunak Sarcophyton sp., terhadap mikroba uji Staphylococus aureus ATCC 25923 mewakili bakteri Gram positif, E. coli ATCC 25922 mewakili bakteri Gram negatif, dan Candida albicans ATCC 1231 mewakili golongan jamur. Tujuan penggunaan mikroba uji ini untuk mengetahui apakah ekstrak kasar dari jamur yang berasosiasi memiliki aktivitas sebagai antimikroba serta apakah mempunyai spektrum luas yaitu dapat membunuh bakteri Gram positif, Gram negatif dan jamur atau mempunyai spektrum yang sempit yang hanya membunuh salah satu dari bakteri Gram positif, Gram nrgatif atau jamur. Ketiga mikroba uji ini ada dalam tubuh manusia. $S$. aureus umumnya ditemukan pada kulit, E. coli umumnya ditemukan di usus, dan C. albicans ditemukan di mulut dan area kelamin.

Pada pengujian aktivitas antimikroba dilakukan dengan menggunakan metode difusi agar. Metode difusi agar adalah metode yang dilakukan dengan pengukuran dan pengamatan diameter zona bening yang terbentuk disekitar cakram yang berisi zat antimikroba yang diletakkan pada media agar yang telah diinokulasi mikroba (Lalamentik, 2017). Tujuan menggunakan metode difusi agar ini untuk melihat sensitivitas berbagai jenis mikroba terhadap antimikroba pada konsentrasi tertentu (Akhyar, 2010). Pengujian antimikroba ini dilakukan dengan pengukuran zona hambat yang terbentuk di area cakram yang bertujuan untuk mengetahui apakah terdapat aktivitas antimikroba dari jamur laut yang berasosiasi dengan karang lunak Sarcophyton sp. Dalam pengujian ini, diperoleh hasil yaitu terbentuknya zona hambat disekeliling cakram yang ditandai dengan adanya area bening. Hal ini menunjukkan bahwa adanya aktivitas anti mikroba terhadap ekstrak jamur yang diisolasi dari karang lunak Sarcophyton sp. Dalam pengujian ini digunakan kontrol positif dan negatif. Penggunaan kontrol positif berfungsi sebagai kontrol dari zat uji, dengan membandingkan diameter daerah hambat yang terbentuk (Dwijendra, 2014). Sedangkan tujuan penggunaan kontrol negatif yaitu untuk mengetahui ada tidaknya pengaruh pelarut terhadap pertumbuhan mikroba uji, sehingga dapat dipastikan bahwa aktivitas yang ditunjukkan oleh ekstrak ialah senyawa yang terkandung dalam sampel bukan berasal dari pelarut yang digunakan. Dalam penelitian ini, kontrol negatif yang digunakan adalah pelarut metanol.

Tabel 1. Hasil pengukuran rata-rata diameter zona hambat

\begin{tabular}{cccc}
\hline & \multicolumn{3}{c}{ Rata - Rata Diameter Total (mm) } \\
\cline { 2 - 4 } $\begin{array}{c}\text { Perlakua } \\
\mathbf{n}\end{array}$ & $\begin{array}{c}\text { Staphylococu } \\
\text { s aureus }\end{array}$ & $\begin{array}{l}\text { Escherichi } \\
\text { a coli }\end{array}$ & $\begin{array}{c}\text { da } \\
\text { albica } \\
\text { ns }\end{array}$ \\
\hline $\begin{array}{c}\text { Ekstrak } \\
\text { Etil } \\
\text { Asetat }\end{array}$ & 0 & 7,19 & 7,49 \\
$\begin{array}{c}\text { Kontrol } \\
\text { Positif } \\
\text { Kontrol } \\
\text { Negatif }\end{array}$ & 26,05 & 21,65 & 23,8 \\
\hline
\end{tabular}

Hasil tersebut diatas berdasarkan pengukuran zona bening yang terbentuk disekitaran kertas cakram. Pengukuran zona hambat dilakukan dengan cara mengukur jarak zona bening secara 
horizontal dan vertikal menggunakan alat jangka sorong (ketelitian 0,01 mm) pada beberapa sisi kertas cakram, lalu dirataratakan. Berdasarkan kriteria Davis and Stout (1971) kategori lemah kurang dari 5 $\mathrm{mm}$, kategori sedang $5 \mathrm{~mm}-10 \mathrm{~mm}$, kategori kuat $10 \mathrm{~mm}-20 \mathrm{~mm}$, kategori sangat kuat lebih dari $20 \mathrm{~mm}$. Dari pengukuran rata-rata diameter zona hambatnya (Tabel 1.) dapat dilihat bahwa daya antimikroba dari sampel karang lunak Sarcophyton sp., pada bakteri uji S. aureus ATCC 25923 tidak ditemukan zona bening hal ini menunjukkan bahwa sampel karang lunak Sarcophyton sp tidak memiliki aktivitas antimikroba terhadap bakteri uji Staphylococcus aureus. Hal ini menunjukkan tidak ada kepekaan mikroba terhadap sampel karang lunak Sarcophyton sp. Sedangkan untuk bakteri E. coli ATCC 25922 terbentuk diameter zona bening sebesar 7,19 mm termasuk dalam kategori sedang, dan untuk jamur $C$. albicans ATCC 1231 terbentuk diameter zona bening sebesar 7,49 $\mathrm{mm}$ termasuk dalam kategori sedang. Pengamatan pada zona hambat ini dilakukan setelah 24 jam masa inkubasi. Berdasarkan hasil yang diperoleh, untuk bakteri Staphylococcus aureus tidak ditemukan daya hambat, hal ini dapat dipengaruhi oleh senyawa bioaktif yang terdapat pada karang lunak Sarcophyton sp. Karang lunak Sarcophyton sp., memiliki kandungan senyawa bioaktif steroid, flavonoid, benedict (Romansyah, 2011). Dari hasil yang diperoleh dapat disimpulkan bahwa jamur yang berasosiasi dengan karang lunak Sarcophyton sp., dari perairan desa Tumbak kecamatan Pusomaen Minahasa Tenggara memiliki spektrum sempit sehingga tidak dapat membunuh bakteri gram positif. Pada penelitian sebelumnya yang di teliti oleh (Fatimawati, 2015) dan (Mokodongan, 2019), menunjukkan bahwa terdapat aktivitas antimikroba yang berbeda-beda pada bakteri Staphylococcus aureus dibuktikan dengan terbentuknya diameter zona hambat. Selanjutnya untuk bakteri E. Coli terdapat aktivitas antimikroba dengan zona hambat sebesar 7,19 mm. Pada penelitian sebelumnya yang diteliti oleh (Hardiningtyas, 2009) dan (mokodongan, 2019) menunjukkan daya hambat yang diperoleh lebih kecil. Selanjutnya untuk jamur Candida albicans terdapat aktivitas antimikroba dengan zona hambat sebesar 7,49 $\mathrm{mm}$. Pada penelitian sebelumnya yang diteliti oleh (mokodongan, 2019) menunjukkan bahwa tidak ada zona hambat yang terbentuk. Hal ini dipegaruhi oleh lingkungan atau tempat pengambilan sampel dan beberapa faktor lainnya seperti $\mathrm{PH}$, suhu,arus dan cahaya.

Spesimen yang berada dilingkungan terbuka dan berombak besar cenderung pendek pertumbuhannya atau juga merambat, sebaliknya spesimen dari jenis yang sama pada lingkungan yang terlindung dari perairan yang lebih dalam dan berarus tenang, pertumbuhannya cenderung tegak dan tinggi sehingga hal ini juga yang dapat mempengaruhi hasil yang di dapat (de Voogd,2005). Sedangkan suhu juga ikut berpengaruh pada senyawa kimia yang terkandung didalam karang lunak Sarcophyton sp., suhu yang terlalu tinggi dapat merusak senyawa kimia yang terdapat pada sampel (Sundari et al, 2015).

Pada penelitian ini menggunakan kontrol positif antibiotik kloramfenikol paper disc, karena kloramfenikol adalah antibiotik yang memiliki spektrum yang 
luas yang mampu menghambat bakteri Gram positif, Gram negatif dan juga dapat menghambat jamur. Kloramfenikol dapat digunakan untuk melawan infeksi yang disebabkan oleh bakteri Gram positif dan bakteri Gram negatif. Kloramfenikol mempunyai khasiat bakterisid (Sumardjo, 2009). Penggunaan kontrol positif berfungsi sebagai kontrol dari zat uji dengan membandingkan diameter hambat yang terbentuk. Dari hasil yang di dapat menunjukan bahwa diameter zona hambat dari kontrol positif pada bakteri Staphylococcus aureus ATCC 2592 26,05 $\mathrm{mm}$ termasuk dalam kategori sangat kuat, Escherichia coli ATCC 25922 21,65 mm termasuk dalam kategori sangat kuat, dan untuk jamur Candida albicans ATCC 1231 23,8 $\mathrm{mm}$ termasuk dalam kategori sangat kuat.

Kontrol negatif yang digunakan pada penelitian ini yaitu metanol, hal ini dikarenakan metanol merupakan pelarut yang digunakan untuk melarutkan sampel. Jika kontrol negatif memiliki daya hambat kemungkinan daya hambat yang diperoleh bisa berasal dari pelarut yang digunakan yaitu metanol. Tetapi, hasil yang diperoleh menunjukkan kontrol negatif menunjukkan tidak adanya zona hambat pada pengujian terhadap bakteri $S$. aureus ATCC 2592, E. coli ATCC 25922, dan jamur C. albicans ATCC 1231. Hal ini menunjukkan bahwa kontrol negatif yang digunakan tidak berpengaruh pada uji antimikroba. Daya hambat yang terbentuk tidak dipengaruhi oleh pelarut melainkan karena aktivitas senyawa yang ada pada karang lunak Sarcophyton sp. Penggunaan metanol sebagai kontrol negatif diperkuat dengan penelitian oleh Ginting (2010), yang menyatakan bahwa kontrol negatif methanol pada uji antibakteri tidak menunjukan adanya aktivitas sehingga dapat dipastikan bahwa metanol tidak berpengaruh terhadap aktivitas yang terbentuk.

\section{KESIMPULAN}

Berdasarkan hasil penelitian yang telah dilakukan dapat disimpulkan bahwa, jamur laut yang berasosiasi dengan karang lunka Sarcophyton sp., yang diperoleh dari Desa Tumbak, Kecamatan Pusomaen, Kabupaten Minahasa Tenggara memiliki aktivitas antimikroba terhadap bakteri, Eschericia coli, dan jamur Candida albicans yang dikategorikan sedang, sedangkan untuk bakteri Staphylococcus aureus tidak memiliki aktivitas antimikroba.

\section{SARAN}

Perlu dilakukan penelitian lebih lanjut uji aktivitas antimikroba menggunakan metode dilusi untuk mengetahui nilai KHM dan KBM dari karang lunak Sarcophyton sp.

Perlu dilakukan penelitian pada uji aktivitas yang lain seperti uji antioksidan.

\section{DAFTAR PUSTAKA}

Akhyar. 2010. Uji Daya Hambat dan Analisis KLT Bioautografi Ekstrak Akar dan Buah Bakau (Rhizophora stylosa Griff.) Terhadap Vibrio Harveyi [skripsi]. Fakultas Farmasi Universitas Hasanuddin, Makassar.

Badria FA, Guirguis AN, Perovic S, Steffen R, Muller WEG, dan Schroder HC. 1998. Sarcophytolide: a new neuroprotective compound from 
Soft coral Sarcophyton glaucum. Toxicology, 131 (3): 133-143.

Benayahu, Y. 1985. Faunistic compotition and pattern in the distribution of softcoral (Octocorallia Alcyonacea) along the coral reefs of Sinai Peninsula. Proc. 5th Int. Coral Reef Symp. Tahiti. 6: 255-260.

Davis, W. W., Stout, T. R. 1971. Disc Plate Method of Microbiological Assay. Journal of Microbiology. 22: 659-665.

De Voogd, N.J. 2005. Indonesian Sponges: Biodiversity and Mariculture Potential, PhD-thesis, University of Amsterdam, the Netherlands.

Dwijendra, I. M. 2014. Aktivitas Antibakteri dan Karakterisasi Senyawa Fraksi Spons Lamellodysidea herbacea yang Diperoleh dari Teluk Manado [skripsi]. Program Studi Farmasi FMIPA Universitas Sam Ratulangi, Manado.

Fatmawati, A. 2015. Uji Aktivitas Ekstrak Karang Lunak Sarcophyton sp terhadap staphylococcus aureus. Jurnal kimia. 3 (1)

Ginting, E. L., Warouw, V., Suleman, R. W. 2010. Aktivitas Antibakteri Dari Ekstrak Kasar Bakteri Yang Berasosiasi Dengan Sponge Acanthostrongylophora sp. [skripsi]. Fakultas Perikanan dan Ilmu Kelautan Universitas Sam Ratulangi, Manado.

Hardiningtyas, S. D. 2009. Aktivitas Antibakteri Ekstrak Karang Lunak Sarcophyton sp. yang Difragmentasi dan Tidak Difragmentasi Di Perairan Pulau
Pramuka, Kepulauan Seribu [skripsi]. FMIPA IPB, Bogor.

Lalamentik, G. 2017. Aktivitas Antibakteri Ekstrak Karang Lunak Klyxum sp. Yang Diperoleh dari Teluk Manado [skripsi]. Fakultas Matematika dan Ilmu Pengetahuan Alam Universitas Sam Ratulangi, Manado.

Mahaza, N.S. 2003. Kajian kerusakan ekosistem terumbu karang akibat penangkapan ikan hias dan pengambilan bunga karang di kelurahan Pulau Panggang Kepulauan Seribu [Skripsi]. Fakultas Perikanan dan Ilmu Kelautan, Institut Pertanian Bogor, Bogor.

Manuputty, A. E. W. 1996. Zooxanthelae pada Karang dan Hubungannya dengan Karakteristik Lingkungan Perairan di Terumbu Karang Pulau Pari, Pulau-pulau Seribu [tesis]. Program Pascasarjana IPB, Bogor.

Mokodongan, T., Simbala, H. E., Rotinsulu, H. 2019. Aktivitas Antimikroba dari Ekstrak dan Fraksi Karang Lunak Sarcophyton sp., dari Perairan Ponteng Desa Tumbak Minahasa Tenggara Terhadap Mikroba Patogen Staphylococcus aureus, Escherichia coli, dan Candida albicans. Jurnal Pharm. 8 (4)

Ortez, J. H. 2005. Disk Diffusion testing in manual of antimicrobial susceptibility testing. Marie B. Coyle (Coord. Ed). American society for Microbiology, America.

Romansyah, Y., 2011., Kandungan Senyawa Bioaktif Antioksidan Karang Lunak Sarcophyton Sp. Alami Dan Transplantasi Di 
Perairan Pulau Pramuka, Kepulauan Seribu [Skripsi]. Departemen Ilmu Dan Teknologi Kelautan Fakultas Perikanan Dan Ilmu Kelautan Institut Pertanian Bogor, Bogor.

Sawant S, Youssef D, Mayer A, Sylvester P, Wall V, Arant M, El-Sayed K. 2006. Anticancer And AntiInflamantory Sulphur-Containing Semisynthetic Derivatives of Sarcophine, Chem, Pharm Bull. 54(8): 1119-1123.

Sumardjo, D. 2009. Pengantar Kimia Buku Panduan Kuliah Mahasiswa Kedokteran dan Program Stratal Fakultas Bioeksakta. EGC, Jakarta.

Sundari , D., Almasyhuri dan Astuti Lamid. 2015. Pengaruh Proses Pemasakan Terhadap Komposisi Zat Gizi Bahan Pangan Sumber Protein.

Van Soest R.W.M. 1989. The Indonesian Sponges Fauna: A Status Report. Ne\&. J. Sea Res. 23 (2). 223-30.

Vandepitte, J; Verhaegen, J; Engbaek, K; Rohner, P; Piot, P; Heuck, C.C. 2011. Prosedur Laboratorium Dasar untuk Bakteriologi Klinis. Edisi 2. Penerbit Buku Kedokteran EGC, Jakarta.

Yamazaki, H., Rotinsulu, H., Kaneko, T., Murakami, K., Fujiwara, H., Ukai, K., Namikoshi, M. 2012. A New Dibenz [b,e] oxepine Derivative, 1Hydroxy-10-Methoxy dibenz [b,e] oxepin-6,11-dione, from a MarineDerived Fungus, Beauveria bassiana TPU942. Journal Marine Drug. 